\title{
118 射出成形品の物性值分布予測手法の検討とそり解析
}

Warp Analysis with Prediction of Property Distribution during Injection Molding
○瀬戸 雅宏（金沢工大）
田中 克（橋本フォーミング(株)）
正山部 昌（金沢工大）

\begin{abstract}
Masahiro SETO, Masashi YAMABE Kanazawa Institute of Technology, 3-1 Yatsukaho, Mattou, 924-0838, Japan. Masaru Tanaka Hashimoto Forming Industry Co. Ltd.

Key Words : Flow Velocity Distribution, Molecular Orientation, Thermal expansion coefficient, Warpage
\end{abstract}

\section{1. 綃言}

射出成形法は，複雑な形状の成形品を短時間に大量に成形でき ることから，プラスチック成形法の中で最も用いられている成形 法である. しかし, 射出成形品には成形後にそり変形が発生しや すい問題がある.このそり変形は, 寸法精度に直接影響するため, 成形現場において重要な問題となっている.

射出成形品のそり変形は, 金型内で泠却する際, 金型内の温度 分布によって冷却速度が異なり收縮差が生じる熱要因と, 成形時 の樹脂流動によって分子か配向して，成形品板厚方向各層で線膨 張係数に異方性や分布が生じ，冷却時に成形品に収縮差が生じる 流動要因の二要因で発生する.

射出成形品に発生するそり変形の対策として，数値シミュレー ションによるそり解析が注目されている.このそり解析を用いて 部品設計や金型設計を行う前に，成形品のそり変形の大きさや方 向を予測することができれば，金型の設計変更や試作の回数か低 減させれ，納期の短縮やコストダウンにつながることから，そり 解析は大変注目されている技術である。

しかし, 現状のそり解析による成形品のそり変形予測は, 金型 内や成形品の温度分布によって生じる収縮差から計算しているが, 分子配向にともなう線膨張係数の異方性や板厚方向の分布が考虑 されていないため, 十分な解析精度が得られていないのが実状で ある。筆者らはこれまで，成形品各層の分子配向度分布を予測す る手法として, 樹脂流動時に発生する成形品板厚方向のせん断応 力分布に着目して, 成形品の分子配向度と関係があることを実験 的に明らかにしてきた ${ }^{1) ， 2)}$.さらに，線脰張(㐿数の異方性と分子 配向度の関係を定量的に比較してきた ${ }^{3)}{ }^{4}$ ）。

本研究では, 成形中におけるせん断応力の時間変化を考虑した せん断ひずみエネルギーを実験的に計測, 算出して, 分子配向度 との比較を行い，分子配向度を予測する手法について検討したの で報告する。

\section{2. せん沂ひずみエネルギー分布と分子四向度}

\section{1 可視化実験の方法}

樹脂流動にともなうせん断ひずみエネルギ一を実験的に求める ため，固定側および可動側金型の一部にガラスブロックを用いた ガラスインサート金型を使用し, 光切断法, PIV 法にて板厚方向 の樹脂流動の観察を行った. その際追跡用粒子には平圴粒径 150

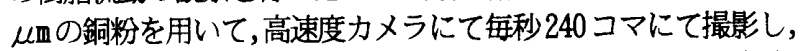
得られた映像から画像処理により樹脂流速分布を求めた. 実験に は GPPS（東洋スチロール製：MT-2）を用い，表 1 に示す条件で 行った. 試験片形状および観察領域を図 1 に示す.

Table 1 Molding conditions

\begin{tabular}{c|c}
\hline Resin temp. & $240^{\circ} \mathrm{C}$ \\
\hline Injection rate & $6.1 \mathrm{~cm}^{3} / \mathrm{s}$ \\
\hline Holding press. & $58.8 \mathrm{MPa}$ \\
\hline Mold temp. & $30^{\circ} \mathrm{C} / 30^{\circ} \mathrm{C}$ \\
\hline
\end{tabular}

2.2 せん断ひずみエネルギーの算出

せん断ひずみエネルギーを算出する際は，樹脂の粘度 $n$ およ゙ 流速分布から得られるせん断ひずみ速度 $\gamma$ から(1)式を用いてせ

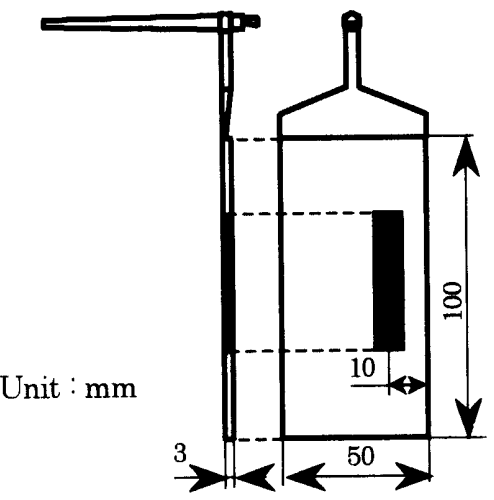

Fig.1 The position of observation

$$
\begin{aligned}
& \tau=\dot{\gamma} \cdot \eta(T, \dot{\gamma}) \\
& P=\tau \cdot \dot{\gamma}
\end{aligned}
$$

ん断応力を算出し,さらに(2)式より単位時間・単位体積当たりの せん断ひずみエネルギー (仕事率) を求めた. 図 2 に成形品の全 板厚を 10 層に分割したときの各層の樹脂流動による仕事率を示 す. 1 層目が成形品表面，2層目が中心層付近である.その結果， 各層で仕事率が大きく異なり, 時間によって変化していることが わかる.

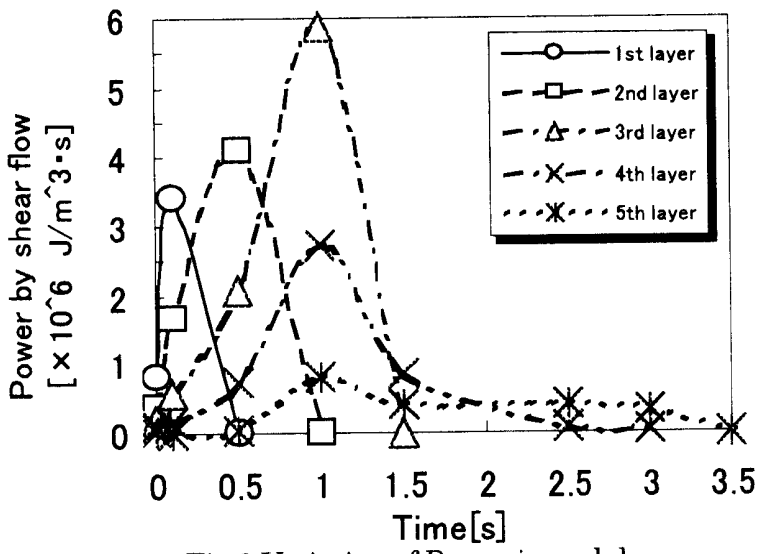

Fig.2 Variation of Power in each layer

分子を配向させるには，外部からのエネルギーが必要であり， 図 2 および(3)式を用いてせん断ひずみエネルギーを算出した。

$$
E=\int_{t_{1}}^{t_{2}} P(t) d t
$$

ここで，積分範囲は厳密には，樹脂が成形中にせん断ひずみエネ ルギーを受けた時間となる. しかし, 可視化実験は定点観察を行 っており，また，分子配向度の測定位置も，観察点と同じ䇢所を 測定している.したがって，せん断ひずみエネルギーが作用して いる全時間で積分すると, 樹脂が流動しているため, 算出される せん断ひずみエネルキーによって分子配向が形成される位置と, 実際に分子配向度を測定した位置か一致しない問題が生じる.そ 
のため, 分子配向度の測定位置において，分子を配向させるエネ ルギーを求めることができるように，積分範囲を設定する必要か ある。

この積分範囲を決定するため，図2の3層目に着目して検討し た. 図 2 において, 観察開始から 1 秒後までは 2 層目も溶融して おり, 2 層目と 3 層目および3 層目と 4 層目の境界層は, 図 3 (左) に示すように樹脂は流動状態である．この状態でも，2 層目と 3 層目および 3 層目と 4 層目の境界層の樹脂流速差から，せん断ひ ずみエネルギーが発生する.しかし，2層目が固化していないこ

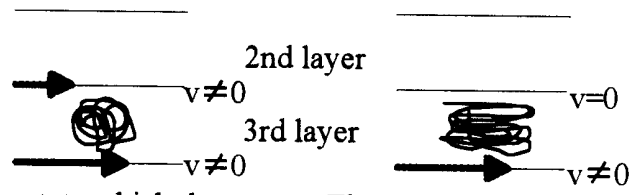

The state which the The state which the $2 \mathrm{md}$ layer has solidified $\quad 2 \mathrm{md}$ layer has not solidified

Fig.3 Integration range for shear strain energy

とから 3 層目の分子鎖は拘束されることはなく，3層目にせん断 ひずみエネルギ一が作用しても，3層目の分子鎖は，比較的自由 に動くことができる．この状態では，分子鎖は配向と緩和を繰り 返しながら流動している状態であり，大きな配向はないと考えら れる.

一方，観察開始 1 秒後から 1.5 秒後までは，2層目が固化した 状態であり，図3（右）に示すように，3層目の樹脂は，2層目 と3層目の境界層付近の固化によって一部が拘束される. その状 態でせん断ひずみエネルギーが作用するため，樹脂は緩和するこ となく, 強く配向すると考えられ，この状態で発生したせん断ひ ずみエネルギーが，支配的に分子を配向させると考えられる．よ って分子配向を形成するせん断ひずみエネルギーを求めるには， 直前の層が固化してから，評価したい層が固化するまでを計算す ることで，分子配向度と比較することができると考えられる。 2.3 せん断ひずみエネルギーと分子配向度の比較

以上の方法で算出した板厚方向各層のせん断ひずみエネルギ 一と成形品各層の分子配向度を比較した結果を図 4 に示す. 分子 配向度の測定は, 可視化実験と同条件で成形した平板の中央部か ら $35 \mathrm{~mm} \times 35 \mathrm{~mm}$ の試験片を切り出し，それを板厚方向に 10 層 に分割してから，分子配向計（王子計測機器製：MOA-3012A） を用いて行った。

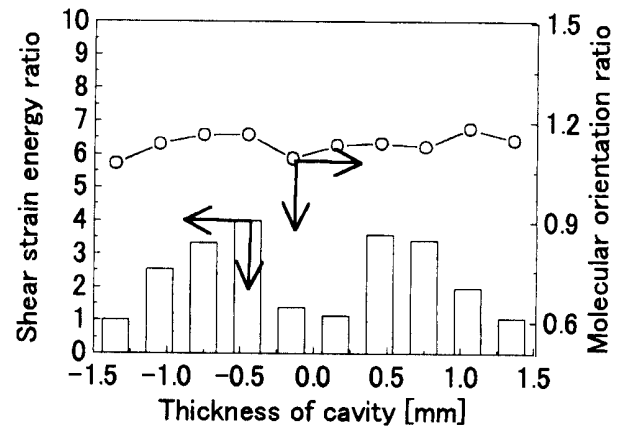

Fig.4 Comparison between molecular orientation and shear strain energy

比較の結果, 各層のせん断ひずみ工ネルギーと分子配向度には 相関が見られた.よって本材料では，せん断ひずみエネルギーから 分子配向度を予測できると考えられる.

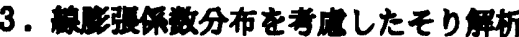

\section{1 線膨張係数分布の予測}

筆者らのこれまでの研究より，線膨張係数の異方性（流れ方向

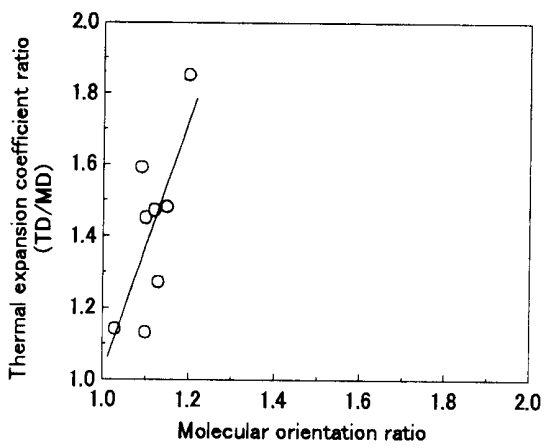

Fig.5 Relation between thermal expansion coefficient ratio and molecular orientation ratio

と直角方向の比）と分子配向度には図 5 に示す関係が得られてい る.この結果を利用して成形品内部の分子配向度分布から各厚み 位置での流れ方向, 直角方向の線膨張係数を求めた.

3.2 板厚方向各層の線膨張係数を考虑したそり解析

そり解析には，PLANETS (プラメディア製) を用いた。解析 モデルは 2 次元 shell 要素を用いてモデル化し, 全厚を5層と仮 定して，各層に前節で求めた流れ方向と直角方向の線膨張係数を 割り付けた. 図6は解析の結果である.成形品にはそり変形が見
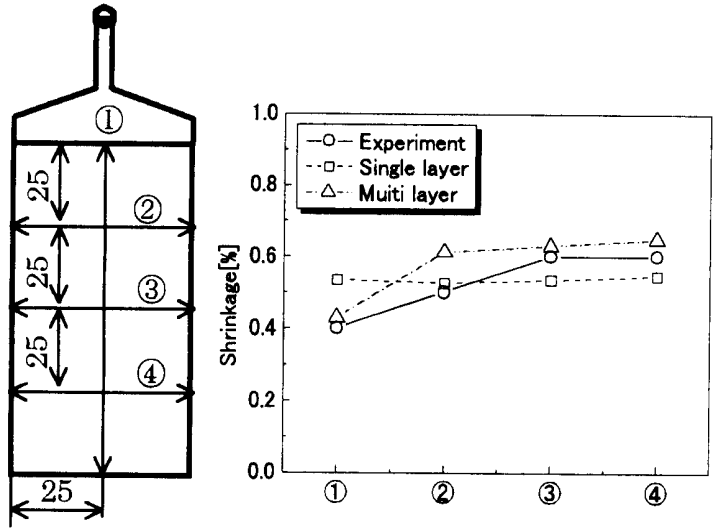

Fig.6 Comparison of shrinkage between experimental data and analysis data

られなかったため，図6に示す 4 力所の収縮率を評価した. その 結果, 各層の線膨張係数分布を考慮した積層モデルでは, 収縮率が 実測之よく一致しており，板厚方向の線膨張俰数分布を考慮したそり 解析は有効であることがわかった。

\section{4. 結音}

・本実験で用いたPS では, 樹脂流動時におけるせん断ひずみエネ ルギーと分子配向度に良い相関関係が得られた。

・板厚方向の線膨張係数分布を考虑する事により,そり解析の精度 が向上することを確認した。

\section{邻辟}

本研究を遂行するにあたり, 東京大学 横井秀俊教授および東京 工業大学 佐藤 烸教授にこ協力いただきました.ここに深謝いた します。

\section{考文献}

1)瀬戸雅宏, 田中克, 佐藤和人, 山部昌 : 成形加工, 14(10), 671 (2002)

2)瀬戸雅宏, 田中克, 山部昌 : 成形加工, 15(5), 363 (2003)

3 )瀬戸雅宏，山部昌 : 成形加工, 13(12)，813(2001)

4)瀬戸雅宏, 寺倉祐二, 佐々木幹生, 山部昌 : 成形加工, 15(2), 149 (2003) 